\title{
Kinetics and mechanism of the reactions of hexaaqua rhodium (III) with sulphur (IV) in aqueous medium
}

\author{
SUPRAVA NAYAK and ANADI C DASH* \\ Department of Chemistry, Utkal University, Bhubaneswar 751 004, India \\ e-mail: acdash1@rediffmail.com
}

MS received 21 November 2003; revised 12 April 2004

\begin{abstract}
An O-bonded sulphito complex, $\mathrm{Rh}\left(\mathrm{OH}_{2}\right)_{5}\left(\mathrm{OSO}_{2} \mathrm{H}\right)^{2+}$, is reversibly formed in the stoppedflow time scale when $\mathrm{Rh}\left(\mathrm{OH}_{2}\right)_{6}^{3+}$ and $\mathrm{SO}_{2} / \mathrm{HSO}_{3}^{-}$buffer $(1<\mathrm{pH}<3)$ are allowed to react. For $\mathrm{Rh}\left(\mathrm{OH}_{2}\right)_{5} \mathrm{OH}^{2+}+$ $\mathrm{SO}_{2} \square \mathrm{Rh}\left(\mathrm{OH}_{2}\right)_{5}\left(\mathrm{OSO}_{2} \mathrm{H}\right)^{2+}\left(k_{1} / k_{-1}\right), \quad k_{1}=(2 \cdot 2 \pm 0 \cdot 2) \times 10^{3} \mathrm{dm}^{3} \mathrm{~mol}^{-1} \mathrm{~s}^{-1}, \quad k_{-1}=0.58 \pm 0 \cdot 16 \mathrm{~s}^{-1} \quad\left(25^{\circ} \mathrm{C}\right.$, $\left.I=0.5 \mathrm{~mol} \mathrm{dm}{ }^{-3}\right)$. The protonated O-sulphito complex is a moderate acid $\left(K_{d}=3 \times 10^{-4} \mathrm{~mol} \mathrm{dm}^{-3}, 25^{\circ} \mathrm{C}\right.$, $\left.I=0.5 \mathrm{~mol} \mathrm{dm}{ }^{-3}\right)$. This complex undergoes $(\mathrm{O}, \mathrm{O})$ chelation by the bound bisulphite with $k=1.4 \times 10^{-3} \mathrm{~s}^{-1}$ $\left(31^{\circ} \mathrm{C}\right)$ to $\mathrm{Rh}\left(\mathrm{OH}_{2}\right)_{4}\left(\mathrm{O}_{2} \mathrm{SO}\right)^{+}$and the chelated sulphito complex takes up another $\mathrm{HSO}_{3}^{-}$in a fast equilibrium step to yield $\mathrm{Rh}\left(\mathrm{OH}_{2}\right)_{3}\left(\mathrm{O}_{2} \mathrm{SO}\right)\left(\mathrm{OSO}_{2} \mathrm{H}\right)$ which further undergoes intramolecular ligand isomerisation to the S-bonded sulphito complex: $\mathrm{Rh}\left(\mathrm{OH}_{2}\right)_{3}\left(\mathrm{O}_{2} \mathrm{SO}\right)\left(\mathrm{OSO}_{2}\right)^{-} \rightarrow \mathrm{Rh}\left(\mathrm{OH}_{2}\right)_{3}\left(\mathrm{O}_{2} \mathrm{SO}\right)\left(\mathrm{SO}_{3}\right)^{-}\left(k_{\text {iso }}=3 \times 10^{-4} \mathrm{~s}^{-1}\right.$, $\left.31^{\circ} \mathrm{C}\right)$. A dinuclear $(\mu-\mathrm{O}, \mathrm{O})$ sulphite-bridged complex, $\mathrm{Na}_{4}\left[\mathrm{Rh}_{2}(\mu-\mathrm{OH})_{2}(\mathrm{OH})_{2}(\mu-\mathrm{OS}(\mathrm{O}) \mathrm{O})\left(\mathrm{O}_{2} \mathrm{SO}\right)\left(\mathrm{SO}_{3}\right)\right.$ $\left.\left(\mathrm{OH}_{2}\right)\right] 5 \mathrm{H}_{2} \mathrm{O}$ with $(\mathrm{O}, \mathrm{O})$ chelated and $\mathrm{S}$-bonded sulphites has been isolated and characterized. This complex is sparingly soluble in water and most organic solvents and very stable to acid-catalysed decomposition.
\end{abstract}

Keywords. Rhodium-sulphur complexes; intramolecular ligand isomerisation; sulphite-bridged complexes.

\section{Introduction}

Rhodium forms a variety of complexes in various oxidation states ranging from +1 to +6 . Interest on the coordination chemistry of rhodium continues to be in accelerating pace due to interesting chemical reactivity, anti tumour activity, electronic structure, and catalytic functions of its complexes with potential industrial applications. ${ }^{1}$

$\mathrm{Rh}^{\mathrm{II}}$ (bipy) ${ }_{2} / \mathrm{Rh}^{\mathrm{III}}$ (bipy) ${ }_{3}$ are believed to be involved in the photo reduction of water. ${ }^{2}$ In recent years, kinetic studies of labile rhodium (II) $\left(4 d^{7}\right)$ complexes $^{3}$ and the relatively more stable rhodium(IV) complexes ${ }^{4}$ have been reported. The most extensive kinetic and structural investigations, however, have centred around low-spin rhodium (III) complexes, ${ }^{1,5(\mathrm{a}-\mathrm{k})}$ of which the hexa-aquarhodium (III), $\mathrm{Rh}\left(\mathrm{OH}_{2}\right)_{6}^{3+}$, is important. Harris et $a l^{5 \mathrm{~b}}$ observed that the rate constants of anation of $\mathrm{Rh}\left(\mathrm{OH}_{2}\right)_{6}^{3+}$ by $\mathrm{Cl}^{-}$and $\mathrm{Br}^{-}$were virtually independent of the anating ligand and compared well with the water exchange rate constant of the aqua cation. On this basis, they proposed a

\footnotetext{
*For correspondence
}

dissociative interchange mechanism for the aqua ligand substitution of $\mathrm{Rh}\left(\mathrm{OH}_{2}\right)_{6}^{3+}$. Recent theoretical studies $^{6}$ and experimental investigations ${ }^{7}$ (i.e. activation volume measurements) of the bromide anation of $\mathrm{Rh}\left(\mathrm{OH}_{2}\right)_{6}^{3+} / \mathrm{Rh}\left(\mathrm{OH}_{2}\right)_{5} \mathrm{OH}^{2+}$ have pointed out that the aqua ligand substitution of $\mathrm{Rh}\left(\mathrm{OH}_{2}\right)_{6}^{3+}$ involves associative interchange mechanism $\left(I_{a}\right)$ while the same for the hydroxopentaaquarhodium (III), $\mathrm{Rh}\left(\mathrm{OH}_{2}\right)_{5} \mathrm{OH}^{2+}$ is essentially dissociative interchange $\left(I_{d}\right)$. However, the possibility of ion-pairing of $\mathrm{Rh}\left(\mathrm{OH}_{2}\right)_{6}^{3+}$ and $\mathrm{Rh}\left(\mathrm{OH}_{2}\right)_{5} \mathrm{OH}^{2+}$ with anionic nucleophiles cannot be overlooked as pointed out by Richens et $a .^{7}$ A further point of interest on the ligand substitution reactions of $\mathrm{Rh}\left(\mathrm{OH}_{2}\right)_{5} \mathrm{X}^{2+}\left(\mathrm{X}=\mathrm{Cl}^{-}\right.$, $\mathrm{Br}^{-}, \mathrm{I}^{-}$and $\left.\mathrm{OH}^{-}\right)$is the trans effect of the ligand $\mathrm{X}^{-}$ which facilitates the substitution of the aqua ligand trans to $\mathrm{X}^{5 \mathrm{~b}, 7}$

It is known that sulphite exerts very strong kinetic and structural trans effects in several (sulphito) aminecobalt (III) complexes in which it is S-bonded to the metal centre. ${ }^{8}$ Such studies on rhodium (III) are rare. There is, however, a report on the formation of the O-bonded sulphito complex, $\mathrm{Rh}\left(\mathrm{NH}_{3}\right)_{5}\left(\mathrm{OSO}_{2}\right)^{+9}$ which is reversibly formed in solution. Ford et $a l^{10}$ 
have investigated the photochemical reactions of trans- $\left(\mathrm{NH}_{3}\right)_{4} \mathrm{Rh}(\mathrm{NCS})\left(\mathrm{SO}_{3}\right)$ and trans $-\mathrm{Rh}\left(\mathrm{NH}_{3}\right)_{4}$ $\left(\mathrm{SO}_{3}\right)_{2}^{-}$(both S-bonded sulphito complexes). The tris sulphito rhodium (III) complexes, $\mathrm{K}_{3}\left[\mathrm{Rh}\left(\mathrm{SO}_{3}\right)_{3}\right] 2 \mathrm{H}_{2} \mathrm{O}$ and $\mathrm{K}_{3}\left[\mathrm{Rh}\left(\mathrm{SO}_{3}\right)_{3}\left(\mathrm{NH}_{3}\right)_{3}\right] 3.5 \mathrm{H}_{2} \mathrm{O}$ have been reportted. ${ }^{11}$ However, the details of cis/trans-labilising action of $\mathrm{O} / \mathrm{S}$-bonded sulphito complexes of $\mathrm{Rh}^{\mathrm{III}}$ have not been investigated in detail although $\mathrm{S}$ bonded sulphite in trans- $\left(\mathrm{NH}_{3}\right)_{4} \mathrm{Rh}(\mathrm{Cl}) \mathrm{SO}_{3}$ has been reported ${ }^{10}$ to exert trans effect.

Our current interest on the reactions of $\mathrm{S}^{\mathrm{IV}}$ with transition metal complexes ${ }^{8,12-14}$ prompted us to investigate the aqua ligand substitution of $\mathrm{Rh}\left(\mathrm{OH}_{2}\right)_{6}^{3+}$ by $\mathrm{S}^{\mathrm{IV}}$ with the intention of examining (i) the mechanism of reaction of $\mathrm{SO}_{2} / \mathrm{HSO}_{3}^{-} / \mathrm{SO}_{3}^{2-}$ with rhodium (III), and (ii) the cis/trans-labilising effect of sulphite if any in the corresponding sulphito complexes. It is pertinent to mention here that $\mathrm{SO}_{2}$ has proved to be a versatile ligand capable of direct coordination to metal centres, especially $\mathrm{Ru}^{\mathrm{II}}$, with several bonding modes, ${ }^{15}$ and $\mathrm{HSO}_{3}^{-} / \mathrm{SO}_{3}^{2-}$ are excellent nucleophiles.

It would be of great interest to examine the possibilities of direct $\mathrm{SO}_{2}$ interaction with $\mathrm{Rh}\left(\mathrm{OH}_{2}\right)_{6}^{3+}$ / $\mathrm{Rh}\left(\mathrm{OH}_{2}\right)_{5}(\mathrm{OH})^{2+}$ replacing the aqua ligand, and insertion of $\mathrm{SO}_{2}$ in $\mathrm{Rh}^{\mathrm{III}}-\mathrm{OH}$, besides substitution of the aqua ligands by $\mathrm{HSO}_{3}^{-} / \mathrm{SO}_{3}^{2-}$.

\section{Experimental}

Solutions of $\mathrm{Rh}\left(\mathrm{OH}_{2}\right)_{6}^{3+}$ in dilute perchloric acid were prepared by digesting $\mathrm{RhCl}_{3} .3 \mathrm{H}_{2} \mathrm{O}$ (JohnsonMathey) with $70 \%$ perchloric acid till free from chloride and diluting to desired volume. The stock solution of $\mathrm{Rh}^{3+}$ (aq.) was diluted appropriately and the $\left[\mathrm{H}^{+}\right]$was estimated by $\mathrm{pH}$ measurements. A standard calibration curve using $\mathrm{HClO}_{4}$ solution of known concentration was used to convert $\mathrm{pH}$ data to $\mathrm{p}\left[\mathrm{H}^{+}\right]=\left(-\log \left[\mathrm{H}^{+}\right]\right){ }^{12 \mathrm{~b}}$ The concentration of $\mathrm{Rh}^{3+}$ in the stock solution was checked spectrophotometrically $\left\{\varepsilon=67.4\right.$ and $62 \mathrm{dm}^{3} \mathrm{~mol}^{-1} \mathrm{~cm}^{-1}$ at 311 and $396 \mathrm{~nm}$ for $\mathrm{Rh}\left(\mathrm{OH}_{2}\right)_{6}^{3+}$ respectively\}. ${ }^{7}$ Analytical grade reagents were used. Sodium meta bisulphite $\left(\mathrm{Na}_{2} \mathrm{~S}_{2} \mathrm{O}_{5}\right)$ (GRE Merck) was the source of $\mathrm{S}^{\mathrm{IV}}$ which in aqueous solution is rapidly hydrolysed to an equilibrium mixture of $\mathrm{SO}_{2} / \mathrm{HSO}_{3}^{-} / \mathrm{SO}_{3}^{2-}$. Fresh solution of $\mathrm{S}^{\mathrm{IV}}$ was prepared every time before starting the kinetics and equilibrium measurements. Sodium perchlorate was prepared by mixing standard solutions of $\mathrm{NaOH}$ and $\mathrm{HClO}_{4}$. The $\mathrm{pH}$ of the stock $\mathrm{NaClO}_{4}$ solution was adjusted to 6 . Freshly prepared doubly distilled water (the second distillation was made from alkaline $\mathrm{KMnO}_{4}$ ) received from a glass distillation apparatus was used for solution preparation.

The $\mathrm{pH}$ measurements were made on a Systronics digital $\mathrm{pH}$ meter model 335 equipped with a combined electrode, CL $51(0<\mathrm{pH}<14)$. The reference electrode was filled with $3 \mathrm{~mol} \mathrm{dm}^{-3} \mathrm{NaCl}$ saturated with $\mathrm{AgCl}$. NBS buffers of $\mathrm{pH} \mathrm{4.01,6.86} \mathrm{and} 9.2$ were used to calibrate the instrument. The spectral measurements and kinetic runs were made using a PC-operated Systonics UV-Visible spectrophotometer model $119 ; 1 \mathrm{~cm}$ matched quartz cells were used. Na was estimated flame photometrically using a Systronics digital flame photometer model 125 and by AAS using a Varian atomic absorption spectrometer Spectro AA $20+$. IR spectra ( $\mathrm{KBr}$ disc) were recorded on Shimadzu 8300 and a Nicolet FTIR spectrometers. Sulphur and hydrogen were analysed on a Perkin-Elmer 240C CHNS analyser.

$\mathrm{Na}_{4}\left[\mathrm{Rh}_{2}(\mathrm{OH})_{4}\left(\mathrm{SO}_{3}\right)_{3}\right], 6 \mathrm{H}_{2} \mathrm{O}$ was prepared as follows. A mixture of $0.5 \mathrm{~g}\left(0.0019\right.$ mole) of $\mathrm{RhCl}_{3}$, $3 \mathrm{H}_{2} \mathrm{O}$ and $0.4 \mathrm{~g}(0.0021$ mole $)$ of $\mathrm{Na}_{2} \mathrm{~S}_{2} \mathrm{O}_{5}$ in $50 \mathrm{~cm}^{3}$ of water was refluxed on a water bath. A white solid formed immediately. Heating was continued for $24 \mathrm{~h}$ after which the solid was collected on a sintered glass funnel (G2), washed with cold water followed by ethanol and ether, and stored over silica gel in a dessicator. Qualitative tests for $\mathrm{Cl}^{-}$using $\mathrm{K}_{2} \mathrm{Cr}_{2} \mathrm{O}_{7}$ and $\mathrm{H}_{2} \mathrm{SO}_{4}$ (chromyl chloride test) was negative while there was reduction of dichromate to $\mathrm{Cr}^{3+}$ thus indicating the presence of sulphite. Analysis: S, 12.5; Rh, 28.5, Na, 12.1, H, 1.91, C, 0.14\%. Calcd. for $\mathrm{Na}_{4} \mathrm{Rh}_{2} \mathrm{~S}_{3} \mathrm{O}_{19} \mathrm{H}_{16}$ (formula wt. $=713 \cdot 8$ ): $\mathrm{S}, 13 \cdot 4$; $\mathrm{Rh}, 28 \cdot 8 ; \mathrm{Na}, 12 \cdot 8, \mathrm{H}, 2 \cdot 2 \%$.

$\mathrm{Rh}^{\text {III }}$ content was analysed by two methods. The complex was decomposed with $70 \% \mathrm{HClO}_{4}$ at sand bath temperature and suitably diluted in distilled water. The absorbance for $\mathrm{Rh}\left(\mathrm{OH}_{2}\right)_{6}^{3+}$ was measured at $396 \mathrm{~nm}$ as mentioned. In a second method, ${ }^{16}$ a known volume of the decomposed complex solution was treated with freshly prepared stannous bromide (using $\mathrm{Sn}$ and $48 \% \mathrm{HBr}$ ) and $70 \% \mathrm{HClO}_{4}$ to develop yellow colour and then diluted to $50 \mathrm{~cm}^{3}\left([\mathrm{Rh}]_{T}=\right.$ $\left.3 \mu \mathrm{g} / \mathrm{cm}^{3}\right)$. Absorbance was measured after $25 \mathrm{~min}$ at $427 \mathrm{~nm}\left(\varepsilon=2.9 \times 10^{4} \mathrm{dm}^{3} \mathrm{~mol}^{-1} \mathrm{~cm}^{-1}\right)$. A blank correction was also applied. $\mathrm{Rh} \%$ calculated by these two methods agreed to $\pm 2 \%$. $^{5 b}$

The fast reactions were studied by a stopped flow spectrophotometer SF 51 (M/s Hitech, UK). The details of the experimental procedure were essentially 
the same as described in our earlier work. ${ }^{12}$ Reaction was studied under pseudo-first order condition with respect to $\left[\mathrm{S}^{\mathrm{IV}}\right]_{T}$ The working wavelength was $290 \mathrm{~nm}$ at which the mixtures of $\mathrm{Rh}^{3+}(\mathrm{aq})$ and $\mathrm{S}^{\mathrm{IV}}$ ( $\mathrm{pH}=1.4-3.0)$ displayed an exponential increase in absorbance with time characteristics of a first-order reaction. At least seven replicate runs were taken for each composition and $k_{\text {obs }}$ data are collected in table 1. Replicate runs using different sets of freshly prepared solutions of a given composition reproduced $k_{\mathrm{obs}}$ within the error limits $\left(\sigma\left(k_{\mathrm{obs}}\right)\right)$.

The slow reactions were monitored by conventional spectrophotometry. The reaction was initiated by mixing the reactants in a volumetric flask $(50,25$ or $10 \mathrm{~cm}^{3}$ ) diluting to the appropriate volume and then transferring the mixture to the spectrophotometric cell. The time delay was noted $(\sim 30 \mathrm{~s})$ and the progress of the reaction was monitored at a suitable wavelength (see table 2). Some runs (at $>30^{\circ} \mathrm{C}$, $k_{\text {obs }}<10^{-4} \mathrm{~s}^{-1}$ ) were also made by batch sampling method which involved thermostatting the reaction mixture in a water thermostat and then drawing samples at known time intervals for absorbance measurements.

All calculations were made on a PC.

\section{Results and discussion}

The UV-Visible spectra of $\mathrm{Rh}\left(\mathrm{OH}_{2}\right)_{6}^{3+},\left[\mathrm{S}^{\mathrm{IV}}\right]$ and a mixture of the two at $\mathrm{pH}=3 \cdot 2$ clearly display an interaction between the two (see figure 1). On mixing the two reactants an absorption maximum appears at $280 \mathrm{~nm}$ instantaneously. The aqua ligand substitution reactions of $\mathrm{Rh}\left(\mathrm{OH}_{2}\right)_{6}^{3+}$ and its aqua-hydroxo analogue are extremely slow. ${ }^{5(\mathrm{~b}-\mathrm{h}), 7}$ For example, the water exchange rate constants $\left(k_{\mathrm{ex}}\right)$ of $\mathrm{Rh}\left(\mathrm{OH}_{2}\right)_{6}^{3+}$ and its aqua-hydroxo analogue, $\mathrm{Rh}\left(\mathrm{OH}_{2}\right)_{5} \mathrm{OH}^{2+}$, are $2.3 \times 10^{-6}$ and $4.2 \times 10^{-3} \mathrm{~s}^{-1}$ at $70^{\circ} \mathrm{C}$ respectively. ${ }^{17}$ It is, therefore, not likely that the direct replacement of the aqua ligand by any of the $\mathrm{S}^{\mathrm{IV}}$ species $\left(\mathrm{SO}_{2}\right.$, $\mathrm{HSO}_{3}^{-}$or $\mathrm{SO}_{3}^{2-}$ ) will be too fast to account for the observed spectral changes. The behaviour of $\mathrm{Rh}\left(\mathrm{OH}_{2}\right)_{6}^{3+}+\mathrm{S}^{\mathrm{IV}}$ is very similar to that of $\left(\mathrm{NH}_{3}\right)_{5}$ $\mathrm{RhOH}_{2}^{3+}+\mathrm{S}^{\mathrm{IV}}$ for which fast formation of the Obonded sulphito complex was observed. ${ }^{9}$ Several (aqua)(amine)cobalt (III) ions have been shown to undergo fast and reversible formation of the O-bonded sulphito complexes in the presence of $\mathrm{SO}_{2}$ in mild acidic media. ${ }^{8}$

On immediate acidification of the reaction mixture of $\mathrm{Rh}\left(\mathrm{OH}_{2}\right)_{6}^{3+}+\mathrm{S}^{\mathrm{IV}}$ to $\mathrm{pH} 1$, the characteristic absorption band at $280 \mathrm{~nm}$, however, intensified. This is due to the strong absorption of $\mathrm{SO}_{2}$ (aq.) $\{\varepsilon$ $(280 \mathrm{~nm})=(2.28 \pm 0.09) \times 10^{2} \mathrm{dm}^{3} \mathrm{~mol}^{-1} \mathrm{~cm}^{-1}$, this work; $\varepsilon \sim 240 \mathrm{dm}^{3} \mathrm{~mol}^{-1} \mathrm{~cm}^{-1}$ at $278 \mathrm{~nm}$ reported by van Eldik $\left.{ }^{9}\right\}$. After correcting for the absorption of $\mathrm{SO}_{2}$ (aq.) it turned out that the instantaneously formed $\mathrm{Rh}^{\mathrm{III}}$-sulphito complex also decayed very rapidly on acidification. Since O-bonded sulphito complexes undergo very rapid acid-catalysed elimination of $\mathrm{SO}_{2},{ }^{5 \mathrm{~g}, 8}$ it is concluded that the rapid spectral changes observed are due to the reversible formation of the O-bonded sulphito complex, $\mathrm{Rh}\left(\mathrm{OH}_{2}\right)_{5}\left(\mathrm{OSO}_{2}\right)^{+}\left\{\lambda \max , \mathrm{nm}\left(\varepsilon \mathrm{dm}^{3} \mathrm{~mol}^{-1} \mathrm{~cm}^{-1}\right)\right.$ : 280 (2700) $\}$ whose spectral parameters agree well with those for $\left(\mathrm{NH}_{3}\right)_{5} \mathrm{Rh}\left(\mathrm{OSO}_{2}\right)^{+}\left\{\lambda \max , \mathrm{nm}\left(\varepsilon \mathrm{dm}^{3}\right.\right.$ $\left.\left.\mathrm{mol}^{-1} \mathrm{~cm}^{-1}\right): 258(\sim 2100)\right\} .9$

The repetitive spectral scans of the reaction mixture on extended time scale displayed profound changes (figure 2) due to the slow secondary reactions of the O-bonded sulphito complex (see later).

$\mathrm{SO}_{2}$ in aqueous medium retains its identity with equilibria as shown below.

$$
\begin{aligned}
& \mathrm{SO}_{2}+\mathrm{H}_{2} \mathrm{O} \rightleftharpoons \mathrm{SHO}_{3}^{-}+\mathrm{H}^{+}, K_{1}, \\
& \mathrm{SHO}_{3}^{-} \rightleftharpoons \mathrm{SO}_{3}^{2-}+\mathrm{H}^{+}, K_{2}, \\
& 2 \mathrm{SHO}_{3}^{-} \rightleftharpoons \mathrm{S}_{2} \mathrm{O}_{5}^{2-}+\mathrm{H}_{2} \mathrm{O}, K_{\mathrm{D}},
\end{aligned}
$$

\begin{tabular}{|c|c|c|c|}
\hline$\left[\mathrm{S}^{\mathrm{IV}}\right]_{T}\left(\mathrm{~mol} \mathrm{dm}{ }^{-3}\right)$ & $\mathrm{pH}$ & $k_{\mathrm{obs}}\left(\mathrm{s}^{-1}\right)$ & $k_{\mathrm{cal}}\left(\mathrm{s}^{-1}\right)$ \\
\hline $0 \cdot 020$ & 2.90 & $1.5 \pm 0.2$ & $1 \cdot 2$ \\
\hline $0 \cdot 040$ & $2 \cdot 96$ & $1.7 \pm 0.2$ & 1.9 \\
\hline $0 \cdot 050$ & $2 \cdot 92$ & $2 \cdot 3 \pm 0 \cdot 2$ & $2 \cdot 3$ \\
\hline $0 \cdot 060$ & 3.00 & $2 \cdot 6 \pm 0.2$ & $2 \cdot 6$ \\
\hline $0 \cdot 080$ & $3 \cdot 06$ & $3 \cdot 3 \pm 0 \cdot 4$ & $3 \cdot 2$ \\
\hline $0 \cdot 100$ & $3 \cdot 01$ & $4.6 \pm 0.7$ & $4 \cdot 0$ \\
\hline $0 \cdot 020$ & 1.47 & $1 \cdot 1 \pm 0 \cdot 2$ & $0 \cdot 86$ \\
\hline $0 \cdot 020$ & $2 \cdot 35$ & $1 \cdot 3 \pm 0.2$ & $1 \cdot 3$ \\
\hline 0.020 & $2 \cdot 92$ & $0 \cdot 90 \pm 0 \cdot 2$ & $1 \cdot 1$ \\
\hline $0 \cdot 020$ & $2 \cdot 24$ & $1 \cdot 2 \pm 0.2$ & $1 \cdot 2$ \\
\hline $0 \cdot 040$ & $1 \cdot 52$ & $1 \cdot 2 \pm 0 \cdot 1$ & $1 \cdot 2$ \\
\hline $0 \cdot 040$ & 1.49 & $1 \cdot 2 \pm 0.2$ & $1 \cdot 2$ \\
\hline $0 \cdot 040$ & $1 \cdot 54$ & $1.4 \pm 0.2$ & $1 \cdot 3$ \\
\hline $0 \cdot 040$ & $1 \cdot 56$ & $1 \cdot 3 \pm 0.2$ & $1 \cdot 3$ \\
\hline $0 \cdot 040$ & $1 \cdot 60$ & $1 \cdot 2 \pm 0 \cdot 2$ & $1 \cdot 3$ \\
\hline
\end{tabular}

Table 1. Rate constants $\left(k_{\text {obs }}\right)$ for the reversible formation of $\left[\mathrm{Rh}\left(\mathrm{OH}_{2}\right)_{5}\left(\mathrm{OSO}_{2} \mathrm{H}\right)\right]^{2+\mathrm{a}}$

$k_{1}\left(\mathrm{dm}^{3} \mathrm{~mol}^{-1} \mathrm{~s}^{-1}\right) ;(2 \cdot 1 \pm 0 \cdot 2) \times 10^{3} ; K_{d}\left(\mathrm{~mol} \mathrm{dm}{ }^{-3}\right) ; 3 \cdot 8 \times$ $10^{-4} ; \quad k_{-1}\left(\mathrm{~s}^{-1}\right) ; 0 \cdot 58 \pm 0 \cdot 16 ; \quad k_{2}\left(\mathrm{dm}^{3} \mathrm{~mol}^{-1} \mathrm{~s}^{-1}\right) ; \quad 0.002 \pm$ $5 \cdot 3 ; F^{\mathrm{b}} 9 \cdot 4$

${ }^{\mathrm{a}} 25 \cdot 0 \pm 0 \cdot 1^{\circ} \mathrm{C} ;\left[\mathrm{Rh}^{\mathrm{III}}\right]_{T}=5 \cdot 0 \times 10^{-4}, I=0 \cdot 5 \mathrm{~mol} \mathrm{dm}{ }^{-3} ; \lambda=$ $290 \mathrm{~nm}$

${ }^{\mathrm{b}} F=$ Ó $\left[\left(k_{\mathrm{cal}}-k_{\mathrm{obs}}\right) / \sigma\left(k_{\mathrm{obs}}\right)\right]^{2}$ 
Table 2. Rate constants for the $(\mathrm{O}, \mathrm{O})$ chelation by $\mathrm{O}$-bonded sulphito complex and formation of the disulphito complex. ${ }^{\mathrm{a}}$

\begin{tabular}{|c|c|c|c|c|c|}
\hline$\left[\mathrm{S}^{\mathrm{IV}}\right]_{T}\left(\mathrm{~mol} \mathrm{dm}{ }^{-3}\right)$ & $\mathrm{pH}$ & $10^{3}{ }_{\mathrm{obs}}^{f}\left(\mathrm{~s}^{-1}\right)$ & $10^{4}{ }_{\mathrm{obs}}^{s}\left(\mathrm{~s}^{-1}\right)$ & $10^{4} k_{\mathrm{cal}}^{s \mathrm{~b}}\left(\mathrm{~s}^{-1}\right)$ & $10^{4} k_{\mathrm{cal}}^{s} \mathrm{c}\left(\mathrm{s}^{-1}\right)$ \\
\hline $0 \cdot 0025$ & $3 \cdot 66$ & $1.78 \pm 0.56$ & $0.99 \pm 0.07$ & 0.68 & $1 \cdot 16$ \\
\hline $0 \cdot 005$ & $3 \cdot 65$ & $1.40 \pm 0.64$ & $1 \cdot 71 \pm 0.22$ & 0.75 & $1 \cdot 15$ \\
\hline $0 \cdot 010$ & $2 \cdot 73$ & $1 \cdot 60 \pm 0 \cdot 19$ & $0 \cdot 33 \pm 0 \cdot 05$ & $0 \cdot 65$ & $0 \cdot 44$ \\
\hline $0 \cdot 010$ & $3 \cdot 11$ & $1.35 \pm 0.15$ & $0.75 \pm 0.09$ & 0.69 & 0.59 \\
\hline $0 \cdot 010$ & $3 \cdot 46$ & $1.51 \pm 0.16$ & $0.84 \pm 0.05$ & $0 \cdot 78$ & $0 \cdot 88$ \\
\hline $0 \cdot 010$ & $3 \cdot 88$ & $1 \cdot 30 \pm 0.23$ & $1.84 \pm 0.08$ & $1 \cdot 04$ & 1.60 \\
\hline $0 \cdot 010$ & $4 \cdot 18$ & $1.54 \pm 0.78$ & $3 \cdot 14 \pm 0 \cdot 35$ & $1 \cdot 45$ & $2 \cdot 41$ \\
\hline $0 \cdot 010$ & $4 \cdot 88$ & $2 \cdot 58 \pm 1 \cdot 36$ & $4 \cdot 70 \pm 0 \cdot 24$ & $4 \cdot 76$ & $4 \cdot 60$ \\
\hline $0 \cdot 015$ & $3 \cdot 58$ & $1.60 \pm 0.26$ & $1.09 \pm 0.08$ & 0.93 & $1 \cdot 04$ \\
\hline $0 \cdot 020$ & $4 \cdot 05$ & $1 \cdot 08 \pm 0 \cdot 21$ & $1.92 \pm 0.03$ & $1 \cdot 84$ & $2 \cdot 03$ \\
\hline 0.030 & $3 \cdot 30$ & $1.52 \pm 0.20$ & $0.77 \pm 0.03$ & 0.94 & 0.73 \\
\hline 0.030 & $3 \cdot 85$ & $2.56 \pm 1.49$ & $1.83 \pm 0.09$ & 1.77 & 1.53 \\
\hline $0 \cdot 040$ & $4 \cdot 11$ & $1 \cdot 76 \pm 0.37$ & $2.90 \pm 0.11$ & $3 \cdot 42$ & $2 \cdot 20$ \\
\hline
\end{tabular}

$k_{1}\left(\mathrm{dm}^{3} \mathrm{~mol}^{-1} \mathrm{~s}^{-1}\right)^{\mathrm{b}}=(0.00014 \pm 99) \times 10^{-4} ; A\left(\mathrm{~s}^{-1}\right)^{\mathrm{c}}=(3.28 \pm 1 \cdot 12) \times 10^{-4}$

$k_{2} K_{h}\left(\mathrm{~s}^{-1}\right)^{\mathrm{b}}=(5.4 \pm 0 \cdot 8) \times 10^{-7} ; B\left(\mathrm{~s}^{-1} \mathrm{~mol} \mathrm{dm}\right)^{-3}=(2 \cdot 27 \pm 0.45) \times 10^{-8}$

$k_{-2}\left(\mathrm{~s}^{-1}\right)^{\mathrm{b}}=0.62 \pm 0.19 ; C(\mathrm{~mol} \mathrm{dm})^{-3}=(3.7 \pm 1.7) \times 10^{-5}$

$K_{h}\left(\mathrm{~mol} \mathrm{dm}^{-3}\right)^{\mathrm{b}}=1.0 \times 10^{-6} ; F^{\mathrm{d}}=274 ; F^{\mathrm{d}}=102$

${ }^{\mathrm{a}} 31.8 \pm 0 \cdot 2^{\circ} \mathrm{C}, I=0.5,10^{4}\left[\mathrm{Rh}^{\mathrm{III}}\right]_{T}=1 \cdot 17$ or $2.4 \mathrm{~mol} \mathrm{dm}{ }^{-3} ; \lambda=250 \mathrm{~nm}$

${ }^{\mathrm{b}}$ Calculated values are based on (6) (see text) using the best fit values of $k_{1}, k_{2} K_{h}, k_{-2}$ and $K_{h}$

${ }^{\mathrm{c}}$ Calculated values are based on (7)

${ }^{\mathrm{d}} F=$ Ó $\left[10^{4}\left(k_{\mathrm{cal}}^{s}-k_{\mathrm{obs}}^{s} / \sigma\left(k_{\mathrm{obs}}^{s}\right)\right]^{2}\right.$

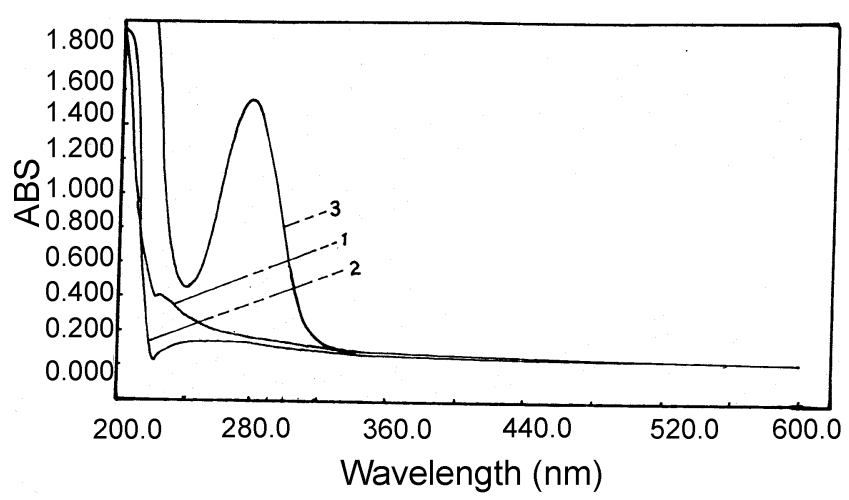

Figure 1. Absorption spectra of $\mathrm{Rh}\left(\mathrm{OH}_{2}\right)_{6}^{3+}+\mathrm{S}^{\mathrm{IV}}$ mixtures. $\left[\mathrm{Rh}\left(\mathrm{OH}_{2}\right)_{6}^{3+}\right]_{T}=5.8 \times 10^{-4},\left[\mathrm{~S}^{\mathrm{IV}}\right]_{T}=5.8 \times 10^{-3} \mathrm{~mol}$ $\mathrm{dm}^{-3}, \mathrm{pH}=3 \cdot 2\left(25^{\circ} \mathrm{C}\right) ;$ (1) $\mathrm{Rh}\left(\mathrm{OH}_{2}\right)_{6}^{3+}$, (2) $\mathrm{S}^{\mathrm{IV}}, \quad$ (3) $\left[\mathrm{Rh}\left(\mathrm{OH}_{2}\right)_{6}^{3+}+\mathrm{S}^{\mathrm{IV}}\right.$.

where $\mathrm{SHO}_{3}^{-}$denotes [bisulphite $]_{T}$ as equilibrium mixture of $\mathrm{H}_{-} \mathrm{SO}_{3}^{-}$and $\mathrm{H}-\mathrm{O}-\mathrm{SO}_{2}^{-}$, the latter species predominating to $>75 \%$. $^{18}$ All experiments were restricted to $\left[\mathrm{S}^{\mathrm{IV}}\right]_{T} \square 0.1 \mathrm{~mol} \mathrm{dm}{ }^{-3} \quad\left(K_{D}=0.082 \mathrm{dm}^{3}\right.$ $\mathrm{mol}^{-1}$ at $\left.25^{\circ} \mathrm{C}, I=1.0 \mathrm{~mol} \mathrm{dm}^{-3}\right)^{19}$ to minimize complications due to dimerisation of bisulphite.

The observed pseudo-first order rate constants for the initial fast reaction of $\mathrm{S}^{\mathrm{IV}}$ with $\mathrm{Rh}\left(\mathrm{OH}_{2}\right)_{6}^{3+}$ are collected in table 1 . The $k_{\mathrm{obs}}$ values are interpreted in terms (see scheme 1) of a fast reaction between $\mathrm{SO}_{2}$ (aq.) and $\mathrm{Rh}\left(\mathrm{OH}_{2}\right)_{5} \mathrm{OH}^{2+} / \mathrm{Rh}\left(\mathrm{OH}_{2}\right)_{6}^{3+}$.

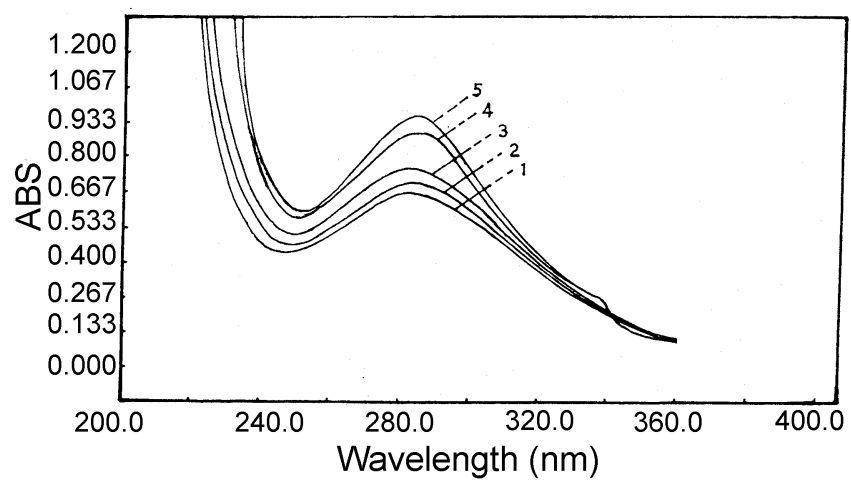

Figure 2. Repetitive spectral scans of $\mathrm{Rh}\left(\mathrm{OH}_{2}\right)_{6}^{3+}+\mathrm{S}^{\mathrm{IV}}$ at $25^{\circ} \mathrm{C} .\left[\mathrm{Rh}^{3+}\right]_{T}=2.4 \times 10^{-4},\left[\mathrm{HSO}_{3}^{-}\right]_{T}=0.01, I=0.5 \mathrm{~mol}$ $\mathrm{dm}^{-3}, \mathrm{pH}=3.60$; Curves generated after $1 \mathrm{~min}(1), 15 \mathrm{~min}$ (2), $40 \mathrm{~min}$ (3), $80 \mathrm{~min}(4)$ and $110 \mathrm{~min}(5)$ of mixing.

In accord with scheme $1, k_{\mathrm{obs}}$ is given by,

$$
\begin{aligned}
& k_{\mathrm{obs}}=\left\{k_{1} f_{3}+k_{2}\left(1-f_{3}\right)\right\} f_{1}\left[\mathrm{~S}^{\mathrm{IV}}\right]_{T}+k_{r}, \\
& \left.k_{r}=k_{-1}+k_{-2}\left[\mathrm{H}^{+}\right]\right) /\left(1+K_{d} /\left[\mathrm{H}^{+}\right]\right),
\end{aligned}
$$

where $f_{1}=\left[\mathrm{H}^{+}\right] /\left(\left[\mathrm{H}^{+}\right]+K_{1}\right)$ (denoting fraction of $\left[\mathrm{S}^{\mathrm{IV}}\right]_{T}$ as $\left.\mathrm{SO}_{2}\right), K_{1}$ is the acid ionisation constant of $\mathrm{SO}_{2}, f_{3}=K_{3} /\left(\left[\mathrm{H}^{+}\right]+K_{3}\right)$ (i.e. the fraction of $\mathrm{Rh}\left(\mathrm{OH}_{2}\right)_{6}^{3+}$ as $\left.\mathrm{Rh}\left(\mathrm{OH}_{2}\right)_{5} \mathrm{OH}^{2+}\right)$, and $K_{3}$ is the acid dissociation constant of $\mathrm{Rh}\left(\mathrm{OH}_{2}\right)_{6}^{3+}$. The ionisation of $\mathrm{HSO}_{3}^{-}$to 
$\mathrm{SO}_{3}^{2-}\left(\mathrm{p} K=6.6 \text { at } 25^{\circ} \mathrm{C}, I=0.5 \mathrm{~mol} \mathrm{dm}{ }^{-3}\right)^{20}$ was neglected. When data were fitted to (4) using $\mathrm{p} K_{1}=1.8\left(I=0.5 \mathrm{~mol} \mathrm{dm}^{-3}, 25.0^{\circ} \mathrm{C}\right)^{20}$ and initially guessed value of $\mathrm{p} K_{3}=3 \cdot 3,{ }^{21}$ the $k_{-2}\left[\mathrm{H}^{+}\right]$term turned out statistically insignificant. Setting $k_{-1}+k_{-2}\left[\mathrm{H}^{+}\right]$as $k_{-1}$ the data were refitted to (4). The best fit value of $\mathrm{p} K_{3}$ turned out to be 3.4 and the calculated parameters are presented in table 1.

It is interesting to note that the $\mathrm{SO}_{2}$ uptake rate constant $\left(k_{1}\right)$ for $\mathrm{Rh}\left(\mathrm{OH}_{2}\right)_{5} \mathrm{OH}^{2+}$ is $10^{5}$ times smaller than the same for $\mathrm{Rh}\left(\mathrm{NH}_{3}\right)_{5} \mathrm{OH}^{2+} \quad\left(k_{1}=1.8 \times\right.$ $10^{8} \mathrm{dm}^{3} \mathrm{~mol}^{-1} \mathrm{~s}^{-1}$ at $\left.25^{\circ} \mathrm{C}, \quad I=1.0 \mathrm{~mol} \mathrm{dm}\right)^{-3}$ but comparable to that of $\mathrm{Cr}\left(\mathrm{OH}_{2}\right)_{5} \mathrm{OH}^{2+}\left(k_{1}=4.4 \times\right.$ $10^{2} \mathrm{dm}^{3} \mathrm{~mol}^{-1} \mathrm{~s}^{-1}$ at $\left.25^{\circ} \mathrm{C}, I=1.0 \mathrm{~mol} \mathrm{dm}{ }^{-3}\right){ }^{22}$ The $k_{1}$ values parallel the basicity of the $\mathrm{M}-\mathrm{OH}^{2+}$ species as adjudged by the $\mathrm{p} K$ of the corresponding aqua cations $\left(\mathrm{p} K_{3}=6.8\right.$ and 3.88 for $\left(\mathrm{NH}_{3}\right)_{5} \mathrm{RhOH}_{2}^{3+}$ and $\mathrm{Cr}\left(\mathrm{OH}_{2}\right)_{6}^{3+}$ respectively at $25^{\circ} \mathrm{C}$ and $I=1.0 \mathrm{~mol}$ $\left.\mathrm{dm}^{-3}\right),{ }^{9,22}$

This is in conformity with Bronstead catalysis law which has been found to be valid for $\mathrm{SO}_{2}$ uptake reactions of metal-hydroxo species. ${ }^{12 \mathrm{c}}$ This work further shows that the reaction of $\mathrm{Rh}\left(\mathrm{OH}_{2}\right)_{6}^{3+}$ with $\mathrm{SO}_{2}$ is statistically insignificant $\left(k_{2}=0.002 \pm 5.3 \mathrm{dm}^{3}\right.$ $\mathrm{mol}^{-1} \mathrm{~s}^{-1}$ at $25^{\circ} \mathrm{C}$, see table 1 ).

The $\mathrm{SO}_{2}$ elimination rate constant of $\mathrm{Rh}\left(\mathrm{OH}_{2}\right)_{5}$ $\left(\mathrm{OSO}_{2} \mathrm{H}\right)^{2+}\left(k_{-1}=0.58 \mathrm{~s}^{-1}\right.$ at $\left.25^{\circ} \mathrm{C}\right)$ is significantly small as compared to that of (tetren) $\mathrm{Co}\left(\mathrm{OSO}_{2} \mathrm{H}\right)^{2+}$ $\left(k_{-1}=1 \times 10^{3} \mathrm{~s}^{-1}, 25^{\circ} \mathrm{C}\right) .^{23}$ The relevant data for other protonated $\mathrm{O}$-sulphito complexes are not available for comparison. Moritzen et $a l^{22}$ did not observe significant protonation of $\mathrm{Cr}\left(\mathrm{OH}_{2}\right)_{5}\left(\mathrm{OSO}_{2}\right)^{+}(0 \cdot 15<$ $\left.\left[\mathrm{H}^{+}\right]<1.0 \mathrm{~mol} \mathrm{dm}{ }^{-3}\right)$ and reported the second order rate constant for $\mathrm{SO}_{2}$ elimination as $1.58 \pm 0.04 \mathrm{dm}^{3}$ $\mathrm{mol}^{-1} \mathrm{~s}^{-1}\left(25^{\circ} \mathrm{C}, I=1.0 \mathrm{~mol} \mathrm{dm}{ }^{-3}\right)$.

The $\mathrm{SO}_{2}$ elimination reaction of $\mathrm{Rh}\left(\mathrm{NH}_{3}\right)_{5}\left(\mathrm{OSO}_{2}\right)^{+}$ was studied by van Eldik ${ }^{9}$ under second order conditions. With a value of $K_{d}=1.0 \times 10^{-4}$ the second

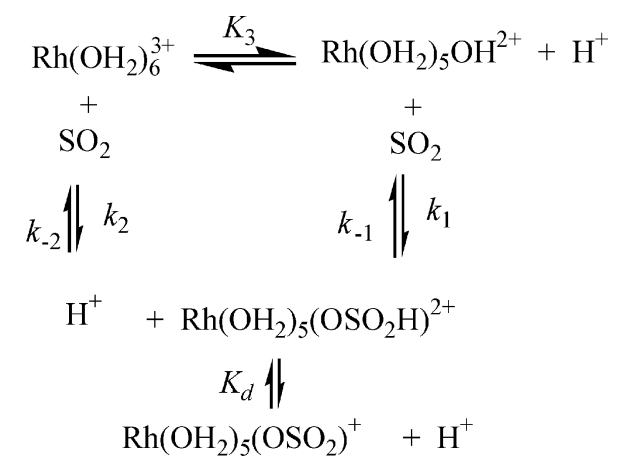

Scheme 1. order rate constant $4.0 \pm 0.8 \times 10^{6} \mathrm{dm}^{3} \mathrm{~mol}^{-1} \mathrm{~s}^{-1}$ $\left(25^{\circ} \mathrm{C}, I=1.0 \mathrm{~mol} \mathrm{dm}^{-3}\right)$ translates to $k_{-1}=4 \times 10^{2} \mathrm{~s}^{-1}$.

This remarkable rate difference for the two rhodium complexes must be due to two factors: (i) ease of intra molecular proton transfer from the coordinated bisulphite to the $\mathrm{Rh}-\mathrm{O}$ bond, and (ii) thermodynamic stability of the hydrogen bonded structure of the bisulphite complex (see figure 3). While the proton transfer will depend upon the basicity of the $\mathrm{Rh}^{\mathrm{III}}-\mathrm{O}$ bond which is expected for $\left(\mathrm{NH}_{3}\right)_{5} \mathrm{Rh}^{\mathrm{III}}-\mathrm{O}$ to be higher than for $\left(\mathrm{OH}_{2}\right)_{5} \mathrm{Rh}^{\mathrm{III}}-\mathrm{O}$, the thermodynamic stability due to hydrogen bonding will be accentuated by the presence of the vicinal aqua ligand. Thus both these effects favour overall stabilization of $\mathrm{Rh}\left(\mathrm{OH}_{2}\right)_{5}\left(\mathrm{OSO}_{2} \mathrm{H}\right)^{2+}$ towards $\mathrm{SO}_{2}$ elimination in comparison to the same for the corresponding ammine complex. It is pertinent to mention here that the stabilizing influence of intra molecular hydrogen bonding in the $\mathrm{SO}_{2}$ elimination of cis [ $\mathrm{Co}(1,3$ diaminopropane $\left.)_{2}\left(\mathrm{OH}_{2}\right)\left(\mathrm{OSO}_{2}\right)\right]^{+}$was observed by us earlier. $^{24}$

A relatively slow reaction was observed when the initially formed O-bonded sulphito complex was allowed to react in excess of $\mathrm{HSO}_{3}^{-}$. The time dependence of the spectral scans of the reaction mixture (see figure 2) showed the gradual build up of the product. This reaction was monitored at $250 \mathrm{~nm}$ (at which the absorbance due $S^{\mathrm{IV}}$ is relatively low) and the absorbance time data under pseudo first order conditions of $\left[\mathrm{S}^{\mathrm{IV}}\right]_{T}$ fitted well to a double exponential equation $\left(A_{\mathrm{obs}}=C_{1} \exp \left(-k_{\mathrm{obs}}^{f} t\right)+C_{2} \exp \left(-k_{\mathrm{obs}}^{s} t\right)+\right.$ $\left.A_{\omega}\right)$ characteristic of consecutive reactions: $\mathrm{R} \rightarrow$ INT $\rightarrow \mathrm{P}$ where $\mathrm{R}$, INT and P denote the reactant, intermediate and the final product respectively. The rate constants, $k_{\mathrm{obs}}^{f}$ and $k_{\mathrm{obs}}^{s}$ are collected in table 2. It is worth noting that $k_{\mathrm{obs}}^{f}$ is virtually independent of $\mathrm{pH}$ and $\left[\mathrm{S}^{\mathrm{IV}}\right]_{T}$ while $k_{\mathrm{obs}}^{s}$ exhibits virtually little $\left[\mathrm{S}^{\mathrm{IV}}\right]_{T}$ but significant $\mathrm{pH}$ dependence. The $k_{\mathrm{obs}}^{s}$ tends to increase with the increase of $\mathrm{pH}$. These results indicate that under the conditions of $\left[\mathrm{S}^{\mathrm{IV}}\right]_{T}$ and $\mathrm{pH}$, rhodium (III) is fully and instantaneously converted

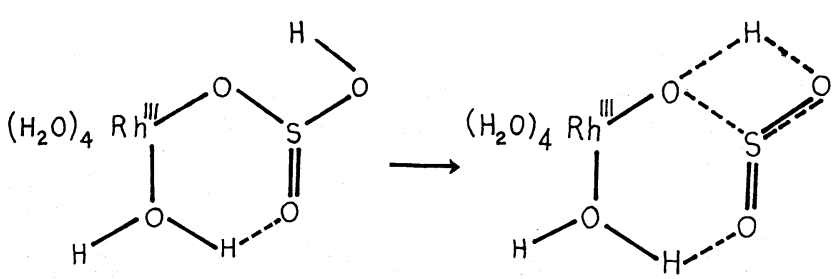

Figure 3. Hydrogen-bonded structure of the rhodium bisulphite complex. 
to the O-bonded sulphito species which then undergoes slow transformation to an intermediate, (5) below. The lack of $\mathrm{pH}$ dependence of $k_{\mathrm{obs}}^{f}(3 \cdot 11 \square$ $\mathrm{pH} \square$ 4.88) is also consistent with the fact that the O-sulphito complex is not appreciably protonated and also there is little specific $\mathrm{H}^{+}$catalysis in its transformation to the intermediate (INT). The average value of $k_{\mathrm{obs}}^{f}$ (weighted mean) is $1.45( \pm 0.02) \times$ $10^{-3} \mathrm{~s}^{-1}\left(31 \cdot 0^{\circ} \mathrm{C}, I=0.5 \mathrm{~mol} \mathrm{dm}{ }^{-3}\right)$.

$$
\mathrm{Rh}\left(\mathrm{OH}_{2}\right)_{5}\left(-\mathrm{OSO}_{2}\right)^{+} \stackrel{k_{\text {obs }}^{f}}{\longrightarrow} \text { INT. }
$$

The two distinct possibilities of reaction (5) are: (i) slow $\mathrm{O}, \mathrm{O}$ chelation of the mono dentate sulphito complex, and (ii) intra molecular $\mathrm{O}$ to S-ligand isomerisation, $\mathrm{Rh}^{\mathrm{IIII}}\left(\mathrm{OH}_{2}\right)_{5}\left(\mathrm{OSO}_{2}(\mathrm{H})\right) \rightarrow \mathrm{Rh}^{\mathrm{III}}\left(\mathrm{OH}_{2}\right)_{5}$ $\left(\mathrm{SO}_{3}\right)$, the $\mathrm{S}, \mathrm{O}$ chelation of sulphite being discounted due to the strained 3-membered ring formation. The $\mathrm{O}$ - to $\mathrm{S}$-bonded ligand isomerisation has been studied for several cobalt(III)-amine-sulphito complexes for which $k_{\text {iso }}$ is essentially $10^{-4} \mathrm{~s}^{-1}$ $\left(25^{\circ} \mathrm{C}\right) .^{8,23,25}$ The $\left[\mathrm{Pt}\left(\mathrm{NH}_{3}\right)_{4}\left(\mathrm{OH}_{2}\right)\left(\mathrm{OSO}_{2}\right)\right]^{2+}$ is reported to isomerise to its $\mathrm{S}$-bonded analogue with $k_{\text {iso }}=4.0 \times 10^{-5} \mathrm{~s}^{-1}\left(25^{\circ} \mathrm{C}\right) .{ }^{26}$ Moritzen et al ${ }^{22}$ reported a value of $2 \times 10^{-4} \mathrm{~s}^{-1}\left(25^{\circ} \mathrm{C}\right)$ for $\mathrm{Cr}\left(\mathrm{OH}_{2}\right)_{5}\left(\mathrm{OSO}_{2}\right)^{+}$. Since S-sulphite is a soft ligand and $\mathrm{Cr}\left(\mathrm{OH}_{2}\right)_{6}^{3+}$ is a hard metal ion, the ligand isomerisation in this system is less likely. On the other hand this could be due to the $\mathrm{O}, \mathrm{O}$ chelation by sulphite. Since the reactions of $\mathrm{Rh}^{\mathrm{III}}$ complexes are slower than those of $\mathrm{Cr}^{\mathrm{III}}$ and $\mathrm{Co}^{\mathrm{III}}, 5 \mathrm{~b}, \mathrm{c,f,h}$ we are led to believe that the reaction (5) is not likely the ligand isomerisation but $\mathrm{O}, \mathrm{O}$ chelation by sulphite. This being an intra molecular process, is likely favoured by the cislabilising effect of the O-bonded sulphite (mono dentate) and accentuated by the presence of the displaceable aqua ligand. It is worth noting that the cis and trans-activation of the O-bonded sulphite has been observed in the $\mathrm{SO}_{3}^{2-} / \mathrm{HSO}_{3}^{-}$catalysed aquation of $\mathrm{Cr}\left(\mathrm{H}_{2} \mathrm{O}\right)_{5} \mathrm{X}^{2+}\left(\mathrm{X}=\mathrm{Cl}^{-}, \mathrm{NCS}^{-}\right)^{27,28}$ and in the aqua ligand substitution of trans- $\left[\mathrm{Cr}(\text { salen })\left(\mathrm{OH}_{2}\right)\left(\mathrm{OSO}_{2}\right)\right]^{-}$ (salen $=\mathrm{N}, \mathrm{N}^{\prime}$-ethylene bis salicylidiniminate) ${ }^{29}$ This is the first report on the cis-activating influence of O-bonded sulphite in a $\mathrm{Rh}^{\mathrm{III}}$-O-sulphito complex.

The chelation reaction (5) is further succeeded by sulphite substitution for the aqua-sulphito complex with which $k_{\mathrm{obs}}^{s}$ is associated. Earlier reports on the halide anation of the $\mathrm{Rh}\left(\mathrm{OH}_{2}\right)_{6}^{3+} / \mathrm{Rh}\left(\mathrm{OH}_{2}\right)_{5} \mathrm{OH}^{2+}$ also demonstrated the formation of the dihalogeno species, $\mathrm{Rh}\left(\mathrm{OH}_{2}\right)_{4}(\mathrm{X})_{2}^{+}\left(\mathrm{X}=\mathrm{Br}^{-}, \mathrm{Cl}^{-}\right)$, the entry of the second halide being much faster than the first one. ${ }^{5 b, 7}$ Scheme 2 and the relevant rate (6) were considered for interpreting the rate data $\left(k_{\mathrm{obs}}^{s}\right)$. The $\left[\mathrm{HSO}_{3}^{-}\right]$values were taken to be $\left(1-f_{1}\right)\left[\mathrm{S}^{\mathrm{IV}}\right]_{T}\left(f_{1}\right.$ as defined above) and $k_{\text {obs }}^{s}$ data were fitted to (6). It turned out that $k_{-1}\left[\mathrm{H}^{+}\right]$term is insignificant and $K_{h}$ (the acid dissociation constant of $\left[\mathrm{Rh}\left(\mathrm{OH}_{2}\right)_{5}\left(\mathrm{O}_{2} \mathrm{SO}\right)\right]^{+}$ is $\quad 1.0 \times 10^{-6} \mathrm{~mol} \mathrm{dm}^{-3}$. Hence the value of $K_{h}$ was held fixed at $1.0 \times 10^{-6}, k_{-1}\left[\mathrm{H}^{+}\right]$term was neglected and the rate constants were refitted to the modified form of (6). The value of $k_{1}$ turned out statistically insignificant and data fitting was also poor (see table 2).

$$
\begin{aligned}
k_{\mathrm{obs}}^{s}=\left(k_{1}+\right. & \left.k_{2} K_{h} /\left[\mathrm{H}^{+}\right]\right)\left[\mathrm{HSO}_{3}^{-}\right] / \\
& \left(1+K_{h} /\left[\mathrm{H}^{+}\right]\right)+k_{-1}\left[\mathrm{H}^{+}\right]+k_{-2} .
\end{aligned}
$$

Interestingly when $k_{\mathrm{obs}}^{s}$ data were fitted to the empirical (7), the fit improved very significantly (see table 2).

$$
k_{\mathrm{obs}}^{s}=\left(A+B /\left[\mathrm{H}^{+}\right]\right) /\left(1+C /\left[\mathrm{H}^{+}\right]\right) .
$$

The values of $A, B$, and $C$ are collected in table 2 . These parameters are interpreted in the frame work of a mechanism for the formation of the disulphito complexes (O- and S-bonded isomers) as depicted in scheme 3 for which $k_{\mathrm{obs}}^{s}$ is given by (8).

$$
\begin{aligned}
k_{\mathrm{obs}}^{s}=\left\{\left(k_{2 \mathrm{iso}}+k_{4} / Q\right)+\right. & \left.k_{3 \text { iso }} K_{d} /\left[\mathrm{H}^{+}\right]\right\} \\
& Q\left[\mathrm{HSO}_{3}^{-}\right] / D_{1}+k_{-4}\left[\mathrm{H}^{+}\right],
\end{aligned}
$$

where

$$
D_{1}=1+Q\left[\mathrm{HSO}_{3}^{-}\right]\left(1+K_{d} /\left[\mathrm{H}^{+}\right]\right) .
$$

$Q$ is the equilibrium quotient for the formation of the disulphito complex, $\left[\mathrm{Rh}\left(\mathrm{OH}_{2}\right)_{3}\left(\mathrm{O}_{2} \mathrm{SO}\right)\left(\mathrm{OSO}_{2} \mathrm{H}\right)\right]$ and $K_{d}$ is its acid dissociation constant. It is further assumed that the reaction of $\mathrm{HSO}_{3}^{-}$with the (aqua)(sulphito) complex to yield, $\mathrm{Rh}\left(\mathrm{OH}_{2}\right)_{3}\left(\mathrm{O}_{2} \mathrm{SO}\right)$

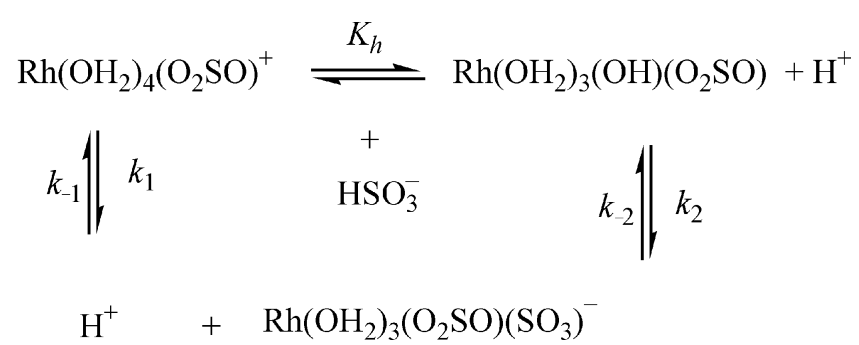

Scheme 2. 


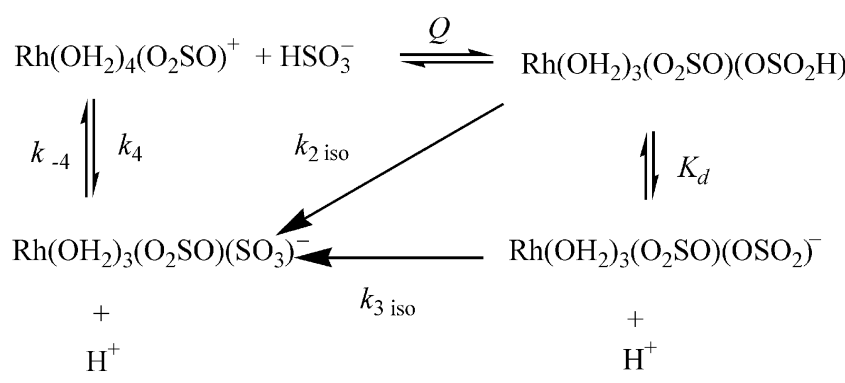

Scheme 3.

$\left(\mathrm{OSO}_{2} \mathrm{H}\right)$ is fast and equilibrium controlled as this is kinetically equivalent to the reaction of the hydroxosulphito complex with $\mathrm{SO}_{2}$ and to that of the fast $\mathrm{SO}_{2}$ addition reaction of $\mathrm{Rh}\left(\mathrm{OH}_{2}\right)_{5} \mathrm{OH}^{2+}$. Assuming that $Q\left[\mathrm{HSO}_{3}^{-}\right]\left(1+K_{d} /\left[\mathrm{H}^{+}\right]\right) \gg 1$, (8) and (9) yield (10) which is essentially equivalent to (7) but for the reverse reaction of the disulphito complex, $\left[\mathrm{Rh}\left(\mathrm{OH}_{2}\right)_{3}\left(\mathrm{O}_{2} \mathrm{SO}\right)\left(\mathrm{SO}_{3}\right)\right]^{-}$. Data fitted to (10) showed that $k_{-4}\left[\mathrm{H}^{+}\right]$is indeed insignificant and hence $A, B, C$ of (7) are reconciled with $\left(k_{2 \text { iso }}+k_{4} / Q\right),\left(k_{3 \text { iso }} K_{d}\right)$ and $K_{d}$ of (10) respectively,

$$
\begin{gathered}
k_{\mathrm{obs}}^{s}=\left\{\left(k_{2 \mathrm{iso}}+k_{4} / Q\right)+k_{3 \mathrm{iso}} K_{d} /\left[\mathrm{H}^{+}\right]\right\} /\left(1+K_{d} /\left[\mathrm{H}^{+}\right]\right) \\
+k_{-4}\left[\mathrm{H}^{+}\right] .
\end{gathered}
$$

The value of $k_{3 \text { iso }}(=B / C)$ is $(6 \cdot 1 \pm 3 \cdot 0) \times 10^{-4} \mathrm{~s}^{-1}$ $\left(31^{\circ} \mathrm{C}\right)$ which reflects the $(\mathrm{O}, \mathrm{O}$ chelated) sulphite induced $\mathrm{O}-$ to $\mathrm{S}$-bonded isomerisation of coordinated (monodentate) sulphite (see scheme 3) in $\left[\mathrm{Rh}\left(\mathrm{OH}_{2}\right)_{3}\right.$ $\left.\left(\mathrm{O}_{2} \mathrm{SO}\right)\left(\mathrm{O}-\mathrm{SO}_{2}\right)\right]^{-}$. Assuming that $k_{2 \text { iso }} \gg k_{4} / Q$, the optimised value of $k_{2 \text { iso }}(=A)$ is $(3 \pm 1) \times 10^{-4} \mathrm{~s}^{-1}$ which is also comparable to the value of $k_{3 \text { iso. }}$.

\section{Equilibrium study for the formation of $\mathrm{Rh}\left(\mathrm{OH}_{2}\right)_{5}\left(\mathrm{OSO}_{2} \mathrm{H}\right)^{2+}$}

An attempt was made to study the initial rapid equilibrium formation of the sulphito complex. The absorbances of the mixtures of $\mathrm{Rh}\left(\mathrm{OH}_{2}\right)_{6}^{3+}$ and $\mathrm{S}^{\mathrm{IV}}$ $\left(I=0.5 \mathrm{~mol} \mathrm{dm}^{-3}\right)$ were measured immediately (within 2 min of mixing) at $280 \mathrm{~nm}$. Data are collected in table 3. Assuming scheme 1 for the rapid and reversible formation of the O-sulphito complex the absorbance data at a fixed total $\left[\mathrm{Rh}^{3+}\right]_{\mathrm{T}}$ and varying $\left[\mathrm{S}^{\mathrm{IV}}\right]_{T}$ and $\mathrm{pH}$ after correcting for the absorbance of $\left[\mathrm{S}^{\mathrm{IV}}\right]_{T}$ is given by (11)

$$
\begin{array}{r}
\ddot{\mathrm{A}} A_{\text {obs }}=\left\{A^{\prime}\left(1+\left[\mathrm{H}^{+}\right] / K_{3}\right)+A^{\prime \prime} K_{\mathrm{eq}} f_{1}\left[\mathrm{~S}^{\mathrm{IV}}\right]_{T}\right\} / \\
\left\{1+\left[\mathrm{H}^{+}\right] / K_{3}+K_{\mathrm{eq}} f_{1}\left[\mathrm{~S}^{\mathrm{IV}}\right]_{T}\right\},
\end{array}
$$

Table 3. Initial rapid equilibrium formation of $\mathrm{Rh}\left(\mathrm{OH}_{2}\right)_{5}\left(\mathrm{OSO}_{2} \mathrm{H}\right)^{2+}$.

\begin{tabular}{lcccc}
\hline$\left[\mathrm{S}^{\mathrm{IV}}\right]_{T}\left(\mathrm{~mol} \mathrm{dm}^{-3}\right)$ & $\mathrm{pH}$ & $A_{\text {obs }}{ }^{\mathrm{b}}$ & $A_{\text {obs }}^{\prime}{ }^{\mathrm{b}}$ & $\ddot{\mathrm{A}} A_{\text {aobs }}{ }^{\mathrm{b}}$ \\
\hline 0.001 & 2.51 & 0.176 & 0.039 & 0.137 \\
0.002 & 2.53 & 0.278 & 0.075 & 0.203 \\
0.003 & 2.56 & 0.388 & 0.105 & 0.283 \\
0.004 & 2.50 & 0.510 & 0.158 & 0.352 \\
0.005 & 2.63 & 0.496 & 0.153 & 0.343 \\
0.006 & 2.68 & 0.562 & 0.167 & 0.396 \\
0.008 & 2.69 & 0.653 & 0.217 & 0.436 \\
0.010 & 2.59 & 0.781 & 0.333 & 0.448 \\
\hline
\end{tabular}

$A_{\text {obs }}^{\prime \prime} K_{\text {eq }}=(7.87 \pm 0.75) \times 10^{3} \mathrm{dm}^{3} \mathrm{~mol}^{-1} ; \quad K_{\text {eq }}=(1.20 \pm$ $0 \cdot 19) \times 10^{4} \mathrm{dm}^{3} \mathrm{~mol}^{-1} ; F^{\mathrm{c}}=0 \cdot 176$

${ }^{\mathrm{a}}\left[\mathrm{Rh}^{\mathrm{III}}\right]_{T}=2.4 \times 10^{-4}, I=0.5 \mathrm{~mol} \mathrm{dm}{ }^{-3}, 30.0^{\circ} \mathrm{C}, \lambda=280 \mathrm{~nm}$, cell path $=1 \mathrm{~cm}$

${ }^{\mathrm{b}} A_{\text {obs }}$ and $A_{\text {obs }}^{\prime}$ denote absorbances of the mixture of $\mathrm{Rh}^{\mathrm{III}}$ and $\mathrm{S}^{\mathrm{IV}}$ and in absence of $\mathrm{Rh}^{\mathrm{III}}$ respectively; $\ddot{\mathrm{A}} A_{\mathrm{obs}}=$ $A_{\text {obs }}-A_{\text {obs. }}^{\prime} . A_{\text {obs }}=0.028$ for $\left[\mathrm{Rh}^{\text {III }}\right]_{T}=2.4 \times 10^{-4} \mathrm{~mol} \mathrm{dm}^{-3}$ at $\mathrm{pH}=2.55 \pm 0.02,\left[\mathrm{~S}^{\mathrm{IV}}\right]_{\mathrm{T}}=0$ and $I=0.5 \mathrm{~mol} \mathrm{dm}^{-3}$ ${ }^{\mathrm{c}} F=$ Ó $\left[10\left(\ddot{\mathrm{A}} A_{\mathrm{obs}}-\ddot{\mathrm{A}} A_{\text {cal }}\right)\right]^{2}$

Table 4. Equilibrium data for the formation of the disulphito complex, $\mathrm{Rh}\left(\mathrm{OH}_{2}\right)_{4}\left(\mathrm{SO}_{3}\right)_{2}^{-{ }^{-a}}$

\begin{tabular}{lccc}
\hline $\begin{array}{l}{\left[\mathrm{S}^{\mathrm{IV}}\right]_{T}} \\
(\mathrm{~mol} \mathrm{dm}\end{array}$ & $\mathrm{pH}$ & $\begin{array}{c}A_{\mathrm{obs}} \\
(280 \mathrm{~nm})\end{array}$ & $\begin{array}{c}A\left(\mathrm{~S}^{\mathrm{IV}}\right)^{\mathrm{b}} \\
(280 \mathrm{~nm})\end{array}$ \\
\hline 0.005 & $3 \cdot 16$ & 0.610 & $0 \cdot 071$ \\
0.010 & 3.49 & 0.747 & 0.094 \\
0.015 & 3.49 & 0.875 & 0.141 \\
0.020 & 3.46 & 0.923 & 0.195 \\
0.030 & 3.46 & 1.142 & 0.292 \\
0.040 & 3.44 & 1.321 & $0 \cdot 398$ \\
0.050 & 3.41 & 1.447 & $0 \cdot 515$ \\
0.030 & 3.14 & 1.247 & $0 \cdot 441$ \\
0.030 & 3.20 & 1.255 & 0.405 \\
0.030 & 3.40 & 1.122 & 0.312 \\
\hline
\end{tabular}

$\left(A^{\prime \prime}-A^{\prime}\right)^{-1} ; \quad 1.87 \pm 0 \cdot 18 ; \quad\left[\left(A^{\prime \prime}-A^{\prime}\right) K_{2 \mathrm{eq}}\right]^{-1} ; 41.7 \pm 3.8 ; A^{\prime}$; $0.41 ; K_{2 \mathrm{eq}}(4.5 \pm 0.6) \times 10^{-2} ; C R C^{\mathrm{c}} ; 0.967$

a $31.0^{\circ} \mathrm{C}, I=0.5 \mathrm{~mol} \mathrm{dm}^{-3}$

${ }^{\mathrm{b}} A\left(\mathrm{~S}^{\mathrm{IV}}\right) \quad(280 \mathrm{~nm})=\varepsilon_{1} \quad f_{1}\left[\mathrm{~S}^{\mathrm{IV}}\right]_{T}+\varepsilon_{2} \quad\left(1-f_{1}\right)\left[\mathrm{S}^{\mathrm{IV}}\right]_{T} ; \quad \varepsilon_{1}=$ $(2.28 \pm 0.09) \times 10^{2}, \varepsilon_{2}=4.95 \pm 0.43 \mathrm{dm}^{3} \mathrm{~mol}^{-1} \mathrm{~cm}^{-1}$

${ }^{\mathrm{c}}$ Corr. coeff. of the double reciprocal plot

where $A^{\prime}$ and $A^{\prime \prime}$ denote $A_{\mathrm{obs}}$ at $\left[\mathrm{S}^{\mathrm{IV}}\right]_{T}=0$ (i.e. for $\mathrm{Rh}^{\mathrm{III}}$ alone at the same $\mathrm{pH}$ and ionic strength) and for the complete transformation of $\left[\mathrm{Rh}^{3+}\right]_{T}$ to its Osulphito complex, $\mathrm{Rh}-\mathrm{OSO}_{2} \mathrm{H}^{2+}$ respectively, $K_{1}, K_{3}$ are as defined earlier, and $K_{\text {eq }}\left(=k_{1} / k_{-1}\right)$ : is the equilibrium constant. Data were fitted to (11) using $\mathrm{p} K_{3}=3.4$ (see above) and $\mathrm{p} K_{1}=1.8$ and we obtained $K_{\text {eq }}=1.2 \quad( \pm 0.2) \times 10^{4} \mathrm{dm}^{3} \mathrm{~mol}^{-1}, \quad A^{\prime \prime} K_{\text {eq }}=(7.87 \pm$ $0.75) \times 10^{3} \mathrm{dm}^{3} \mathrm{~mol}^{-1} \quad\left(31.0^{\circ} \mathrm{C}, \quad I=0.5 \mathrm{~mol} \mathrm{dm}^{-3}\right)$, and $\varepsilon(80 \mathrm{~nm})=2,728 \pm 500 \mathrm{dm}^{3} \mathrm{~mol}^{-1} \mathrm{~cm}^{-1}\left(\varepsilon=A^{\prime \prime} /\right.$ 
Table 5. Infrared data of some sulphito complexes.

\begin{tabular}{|c|c|c|c|c|}
\hline \multirow{2}{*}{$\begin{array}{l}\text { Complex } \\
\mathrm{K}_{6}\left[\mathrm{Pt}\left(\mathrm{SO}_{3}\right)_{4}\right] 2 \mathrm{H}_{2} \mathrm{O}^{\mathrm{a}}\end{array}$} & \multicolumn{4}{|c|}{ Frequency $\left(\mathrm{cm}^{-1}\right)$} \\
\hline & 1082,1057 & 964 & 660 & 540 \\
\hline Cis- $\mathrm{K}_{2}\left[\mathrm{Pd}\left(\mathrm{SO}_{3}\right)_{2}\left(\mathrm{NH}_{3}\right)_{2}\right]^{\mathrm{a}}$ & 1093,1056 & $995,977,958,831,792,771$ & 655,622 & $569,522,505$ \\
\hline Trans $-\mathrm{K}_{2}\left[\mathrm{Pd}\left(\mathrm{SO}_{3}\right)_{2}\left(\mathrm{NH}_{3}\right)_{2}\right]^{\mathrm{a}}$ & 1074 & $986,958,837,812$ & 646 & 525,511 \\
\hline $\mathrm{K}_{3}\left[\mathrm{Rh}\left(\mathrm{SO}_{3}\right)_{3}\left(\mathrm{NH}_{3}\right)_{3}\right] 3 \cdot 5 \mathrm{H}_{2} \mathrm{O}^{\mathrm{a}}$ & $1107,1056,1017$ & 954,800 & 638 & 524 \\
\hline $\mathrm{K}_{3}\left[\mathrm{Rh}\left(\mathrm{SO}_{3}\right)_{3}\right] 2 \mathrm{H}_{2} \mathrm{O}^{\mathrm{a}}$ & $1157,1113,1058$ & 939 & 690,647 & 527 \\
\hline $\mathrm{K}_{2}\left[\mathrm{Pd}\left(\mathrm{SO}_{3}\right)_{2}\right]^{\mathrm{a}}$ & $1157,1099,1056$ & 933,904 & 664,637 & $563,516,497$ \\
\hline $\mathrm{K}_{2}\left[\mathrm{Pt}\left(\mathrm{SO}_{3}\right)_{2}\right] 2 \mathrm{H}_{2} \mathrm{O}^{\mathrm{a}}$ & $1166,1092,1036$ & 977 & & \\
\hline$\left[\mathrm{Co}\left(\mathrm{NH}_{3}\right)_{5}\left(\mathrm{SO}_{3}\right)\right] \mathrm{Cl}^{\mathrm{a}}$ & 1110 & 985 & 633 & 519 \\
\hline$\left[\mathrm{Co}\left(\mathrm{NH}_{3}\right)_{5}\left(\mathrm{SO}_{3}\right)\right] \mathrm{Cl}, \mathrm{H}_{2} \mathrm{O}^{\mathrm{b}}$ & 1105 & 994,985 & 640 & 525 \\
\hline $\begin{array}{l}{\left[\mathrm{N}_{3} \mathrm{Cr}(\mu-\mathrm{OH})_{2}(\mu-\mathrm{OS}(\mathrm{O}) \mathrm{O}) \mathrm{CrN}_{3}\right]\left(\mathrm{ClO}_{4}\right)_{2}} \\
3 \mathrm{H}_{2} \mathrm{O}^{\mathrm{c}}\end{array}$ & & $974,940,912,832,866$ & 640 & \\
\hline $\begin{array}{l}\mathrm{Na}_{4}\left[(\mathrm{HO})\left(\mathrm{SO}_{3}\right)-\mathrm{Rh}(\mu-\mathrm{OH})_{2}(\mu-\mathrm{OS}(\mathrm{O}) \mathrm{O})\right. \\
\left.\quad \mathrm{Rh}(\mathrm{OH})\left(\mathrm{SO}_{3}\right)\right], 6 \mathrm{H}_{2} \mathrm{O}^{\mathrm{d}}\end{array}$ & $1175,1121,1067$ & 957 & 689,642 & 552,523 \\
\hline $\mathrm{Cu}_{3}(\mu-\mathrm{O}-\mathrm{S}(\mathrm{OH}) \mathrm{O})_{2}(\mathrm{salpd})_{2}\left(\mathrm{OH}_{2}\right)_{2}{ }^{\mathrm{e}}$ & 1057,1038 & 853 & 617 & 585 \\
\hline
\end{tabular}

${ }^{\mathrm{a}} \operatorname{Ref} 11(\mathrm{~b}) ;{ }^{\mathrm{b}} \operatorname{Ref}(33) ;{ }^{\mathrm{c}} \operatorname{Ref}(31) ;{ }^{\mathrm{d}} \mathrm{This}$ work; ${ }^{\mathrm{e}} \operatorname{Ref}(30)$

$\left.\left[\mathrm{Rh}^{3+}\right]_{T}\right)$ for the O-sulphito complex. From kinetic data we obtained $K_{\text {eq }}\left(=k_{1} / k_{-1}\right)$ as $(4 \pm 1) \times 10^{3} \mathrm{dm}^{3}$ $\mathrm{mol}^{-1}$. The agreement between the two sets of values is good considering the competing secondary reactions.

The equilibrium for the formation of the disulphito complex, $\mathrm{Rh}\left(\mathrm{OH}_{2}\right)_{3}\left(\mathrm{O}_{2} \mathrm{SO}\right)\left(\mathrm{SO}_{3}\right)^{-}$(see scheme 3) was also studied at constant $\left[\mathrm{Rh}^{\mathrm{III}}\right]_{T}$ and varying $\left[\mathrm{S}^{\mathrm{IV}}\right]_{T}$. The mixed solutions of appropriate compositions were equilibrated for ca. $10 t_{1 / 2}$ as judged by the values of $k_{\mathrm{obs}}^{s}$. The absorbance data $(280 \mathrm{~nm})$ of the equilibrium mixtures $\left(\left[\mathrm{S}^{\mathrm{IV}}\right]_{T} \gg\left\{\left[\mathrm{Rh}^{\mathrm{III}}\right]_{T}, I=0.5\right.\right.$ mol dm${ }^{-3}$ ) after correcting for the absorbance of $\mathrm{S}^{\mathrm{IV}}$ ( $\left.\ddot{\mathrm{A}} A_{\text {obs }}\right)$ were fitted to $(12 \mathrm{~b})$, the linearized form of (12a) where $K_{2 \mathrm{eq}}\left(=k_{4} / k_{-4}\right)$ is the equilibrium constant for the formation of the disulphito complex: $\mathrm{Rh}\left(\mathrm{OH}_{2}\right)_{4}\left(\mathrm{O}_{2} \mathrm{SO}\right)^{+}+\mathrm{HSO}_{3}^{-} \square \mathrm{Rh}\left(\mathrm{OH}_{2}\right)_{3}\left(\mathrm{O}_{2} \mathrm{SO}\right)$ $\left(\mathrm{SO}_{3}\right)^{-}+\mathrm{H}^{+}\left(K_{2 \mathrm{eq}}\right), A^{\prime}$ and $A^{\prime \prime}$ denote the absorbances of $\left(\mathrm{Rh}\left(\mathrm{OH}_{2}\right)_{4}\left(\mathrm{O}_{2} \mathrm{SO}\right)^{+}\right.$and $\mathrm{Rh}\left(\mathrm{OH}_{2}\right)_{3}\left(\mathrm{O}_{2} \mathrm{SO}\right)\left(\mathrm{SO}_{3}\right)^{-}$ respectively for the same $\left[\mathrm{Rh}^{\mathrm{III}}\right]_{T}$.

$$
\begin{aligned}
\ddot{\mathrm{A}} A_{\mathrm{obs}}= & \left(A^{\prime}+A^{\prime \prime} K_{2 \mathrm{eq}}\left[\mathrm{HSO}_{3}^{-}\right] /\left[\mathrm{H}^{+}\right]\right) / \\
& \left(1+K_{2 \mathrm{eq}}\left[\mathrm{HSO}_{3}^{-}\right] /\left[\mathrm{H}^{+}\right]\right) \\
\left(\ddot{\mathrm{A}} A_{\mathrm{obs}}-A^{\prime}\right)^{-1}=\left(A^{\prime \prime}-A^{\prime}\right)^{-1} & +\left[\left(A^{\prime \prime}-A^{\prime}\right) K_{2 \mathrm{eq}}\right]^{-1} \mathrm{X}\left[\mathrm{H}^{+}\right] /\left[\mathrm{HSO}_{3}^{-}\right] .
\end{aligned}
$$

The relevant data are collected in table 4 . The direct sulphite substitution rate constant $\left(k_{4}\right)$ may be $10^{-5}$ $\mathrm{dm}^{3} \mathrm{~mol}^{-1} \mathrm{~s}^{-1}\left(31^{\circ} \mathrm{C}\right)$ based on which $k_{-4}\left(=k_{4} / K_{2 \mathrm{eq}}\right)$ is ca. $\sim 2 \times 10^{-4} \mathrm{dm}^{3} \mathrm{~mol}^{-1} \mathrm{~s}^{-1}$ supporting the validity of (7) under the experimental conditions (i.e. insignificant $k_{-4}\left[\mathrm{H}^{+}\right]$term, see scheme 3 ).

\section{Nature of the sulphito complex, $\mathrm{Na}_{4}\left[\mathrm{Rh}_{2}(\mathrm{OH})_{4}\left(\mathrm{SO}_{3}\right)_{3}\right] 6 \mathrm{H}_{2} \mathrm{O}$ and its reactions}

This sulphito complex was isolated as an amorphous white solid, very slightly soluble in water and most organic and aquo-organic solvents. The IR spectrum of the complex is compared with those of several other sulphito complexes in table 5. The presence of water is indicated by strong bands at 3448 and 1637 . Multiple bands at 1067-1175 (see table 5) are assigned to the asymmetric $\mathrm{S}=\mathrm{O}$ stretching of the coordinated sulphite which is split due to the reduction of the local symmetry of the coordinated sulphite from $\mathrm{C}_{3 \mathrm{~V}}\left(\mathrm{M}-\mathrm{SO}_{3}\right)$ to $\mathrm{Cs}\left(\mathrm{M}-\mathrm{OSO}_{2}\right.$ or $\left.\mathrm{M}-\mathrm{O}_{2} \mathrm{SO}\right) .{ }^{11 \mathrm{~b}}$ The IR spectrum of the complex shows some similarity with that of $\mathrm{Na}_{3} \mathrm{Rh}\left(\mathrm{SO}_{3}\right)_{3},{ }^{11 \mathrm{~b}}\left[\mathrm{Cu}_{3}(\mu-\mathrm{OS}(\mathrm{OH})\right.$ $\left.\mathrm{O})_{2}(\mathrm{salpd})_{2}\left(\mathrm{OH}_{2}\right)_{2}\right]^{30}$ and $\left[\mathrm{N}_{3} \mathrm{Cr}(\mu-\mathrm{OH})_{2}(\mu-\mathrm{OS}(\mathrm{O})\right.$ $\left.\mathrm{OCrN}_{3}\right] \quad\left(\mathrm{N}_{3}-\mathrm{a}\right.$ tridentate $\mathrm{N}$-donor ligand) ${ }^{31}$ (see table 5); in the tris-sulphito rhodium complex $(\mathrm{O}, \mathrm{O})$ chelation by sulphite has been suggested while $\mathrm{SO}_{3}^{2-}$ and $\mathrm{HSO}_{3}^{-}$act as $(\mathrm{O}, \mathrm{O})$ bridges between the metal centres in the latter two complexes. It is also worth noting that the IR spectrum of $\mathrm{K}_{3}\left[\mathrm{Rh}\left(\mathrm{SO}_{3}\right)_{3}\left(\mathrm{NH}_{3}\right)_{3}\right]$ $3.5 \mathrm{H}_{2} \mathrm{O}$ (see table 5) which has $\mathrm{S}$-bonded sulphite shows multiplets at 1017-1107 while that of trans$\mathrm{K}_{2}\left[\mathrm{Pd}\left(\mathrm{SO}_{3}\right)_{2}\left(\mathrm{NH}_{3}\right)_{2}\right]$ shows one band at $1074 \mathrm{~cm}^{-1}$. The disodium trans-disulphitodiamminepalladate (II) hexahydrate has been structurally characterised ${ }^{32}$ to have $\mathrm{Pd}-\mathrm{S}$ coordination and $\mathrm{Co}-\mathrm{S}$ bond exists in $\left(\mathrm{NH}_{3}\right)_{5} \mathrm{CoSO}_{3}^{+}$(ref 33). We are led to believe that the rhodium (III)-sulphite complex which we report has both mono dentate $\mathrm{S}$ - and $(\mathrm{O}, \mathrm{O})$ chelated sulphite and a bridging $(\mu-\mathrm{OS}(\mathrm{O}) \mathrm{O})$ sulphite (tentative struc- 


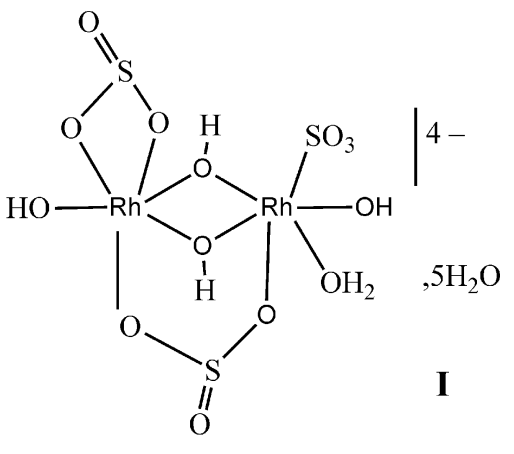

ture I). The kinetic results discussed earlier are in favour of the proposed bonding modes of sulphite ( $\mathrm{O}, \mathrm{O}$ chelation and $\mathrm{S}$-coordination).

The $\mu-\mathrm{O}, \mathrm{O}$ sulphite bridge for the $\mathrm{Cr}(\mathrm{III})$ complex reported by Maragh $e t a l^{31}$ has exceptional stability towards acid catalysed aquation in preference to the hydroxo-bridge cleavage. Our complex was also very stable to decomposition in strongly acidic medium. A preliminary specrophotometric measurements $(280 \mathrm{~nm}$, initial rate method) of the acid induced decomposition of this complex in $1 \mathrm{~mol}$ $\mathrm{dm}^{-3} \mathrm{HClO}_{4}$ yielded $k=5 \times 10^{-6} \mathrm{~s}^{-1}$ at $50^{\circ} \mathrm{C}$.

\section{Acknowledgements}

This work was supported by a research grant to ACD by the Council of Scientific \& Industrial Research, New Delhi. SN is thankful to the CSIR for a fellowship. Our sincere thanks are due to Professor Goutam K Lahiri, IIT, Mumbai, and Professor Pradyot Banerjee, IACS, Kolkata, for IR measurements and elemental analysis (C $\mathrm{H} \mathrm{S}$ ). We thank $\mathrm{G} \mathrm{S}$ Brahma and B Sahu for assistance.

\section{References}

1. (a) Constable C 1986 Coordination Chem. Rev. 73 69; (b) Pruchnik F P, Jutarska A, Ciunik Z and Pruchnik M 2003 Inorg. Chim. Acta 350 609; (c) Pruchnik F P, Jakimowicz P, Ciunik Z, Stanislawek $\mathrm{K}$, Oro L A, Tejel C and Ciriano M A 2001 Inorg. Chem. Commun. 4 19; (d) Pruchnik F P, Jackimowicz $\mathrm{P}$ and Ciunik Z 2001 Inorg. Chem. Commun. 4 726; (e) Cotton F A and Walton R A 1993 Multiple bonds between metal atoms (Oxford: Clarendon Press); (f) Padwa A, Austin D J and Hornbuckle S F 1996 J. Org. Chem. 61 63; (g) Crawford C A, Matonic J H, Huffman K, Folting K, Dunbar K R and Christou G 1997 Inorg. Chem. 36 2361; (h) Dunbar K R, Matonik J H, Saharan V P, Crawford C A and Christou G 1994 J. Am. Chem. Soc. 1162201
2. (a) Kirch M, Lehn J M and Sauvage J P 1979 Helv. Chim. Acta 62 1345; (b) Brown G M, Chan S-F, Creutz C, Schwarz H A and Sutin N J 1979 J. Am. Chem. Soc. 101 7638; (c) Chan S-F, Chou M, Creutz C, Matsubara T and Sutin N $1981 \mathrm{~J}$. Am. Chem. Soc. 103369

3. Schwarz H A and Creutz C 1983 Inorg. Chem. 22 707

4. Pestovsky O and Bakac A 2002 Inorg. Chem. 41 3575 , and references cited therein

5. (a) Johnson S A and Basolo F 1962 Inorg. Chem. 1 925; (b) Buchacek R J and Harris G M 1976 Inorg. Chem. 13 925; (c) Pavelich M J, Maxey S M and Pfaff R C 1978 Inorg. Chem. 17 564; (d) Hyde K, Kelm H and Palmer D A 1978 Inorg. Chem. 17 1647; (e) Weber W, van Eldik R, Kelm H, Dibeneditts J, Ducommun Y, Offen H and Ford P C 1983 Inorg. Chem. 22 623; (f) Cloete E, Breet E and van Eldik R 1995 J. Chem. Soc., Dalton Trans. 3591; (g) Palmer D A and van Eldik R 1983 Chem. Rev. 83 651; (h) Langford C H and Sastri V S 1972 In MTP International Review of Science (ed.) M L Tobe (London: Butterworths) p. 203; (i) Paul P, Tyagi B, Bilakhiya A K, Bhadbhade M M, Suresh E and Ramchandraiah G 1998 Inorg. Chem. 37 5733; (j) Bhaduri S, Lahiri G K and Munshi P 2000 J. Organomet. Chem. 606 151; (k) S-Eveland R A, Nguyen S J, L-Sands L M and Rheingold A L 2000 Inorg. Chem. 392452

6. Vito D D, Sidorenkova H, Rotzinger F P, Weber J and Merbach A E 2000 Inorg. Chem. 39 5547, and references cited therein

7. Galbraith S C, Robson C R and Richens D T $2002 \mathrm{~J}$. Chem. Soc., Dalton Trans. 4335

8. (a) Dash A C 2000 J. Indian Chem. Soc. 77 583; and references cited therein; (b) Pratt J M and Thorp R G 1969 Adv. Inorg. Chem. Radiochem. 12375

9. Van Eldik R 1980 Inorg. Chim. Acta 4249

10. Carlos R M, Frink M E, Tloun E and Ford P C 1992 Inorg. Chim. Acta 193159

11. (a) Lebedinskii V V and Shenderetskaya $1957 \mathrm{Zh}$. Neorg. Khim. 2 1768; (b) Newman G and Powell D B 1963 Spectrochim. Acta 19213

12. (a) Das A and Dash A C 2000 Indian J. Chem. A39 902; (b) Das A and Dash A C 2000 J. Chem. Soc., Dalton Trans. 1949; (c) Dash A C and Das A 1999 Int. J. Chem. Kinet. 31 627; (d) Das A and Dash A C 2000 Inorg. React. Mech. 2101

13. Dash A C and Brahma G S 2003 Indian J. Chem. A42 53

14. Nayak S and Dash A C 2003 Indian J. Chem. A42 2427

15. (a) Kovalevsky A Yu, Bagley K A and Coppens $\mathrm{P}$ 2002 J. Am. Chem. Soc. 124 1241; (b) Kovalevsky A Yu, Bagley K A, Cole J M and Coppens P 2003 Inorg. Chem. 42140

16. Berman S S and Ironside R 1958 Can J. Chem. 36 1151

17. Laurence G, Rapaport I, Zbinden D and Merbach A E 1991 Magn. Reson. Chem. 29845

18. Horner D A and Connick R E 2003 Inorg. Chem. 42 1994 
19. Connick R E, Tam T M and von Deuster L 1982 Inorg. Chem. 21103

20. Brandt C and van Eldik R 1995 Chem. Rev. 95119

21. Ghosh A K, Ghosh C and De G S 1996 Indian J. Chem. A35 342

22. Moritzen P A, El-Awady A A and Harris G M 1985 Inorg. Chem. 24313

23. Dash A C, El-Awady A A and Harris G M 1981 Inorg. Chem. 203160

24. Dash A C, Jena K C, Roy A, Mukherjee D and Aditya S 1997 J. Chem. Soc., Dalton Trans. 2451

25. Kraft J and van Eldik R 1985 Inorg. Chem. 243391

26. Koshy K C and Harris G M 1983 Inorg. Chem. 22 2947
27. Carlyle D W and King E L 1970 Inorg. Chem. 92333

28. Choi S N and Carlyle D W 1974 Inorg. Chem. 13 1027

29. Dash A C, Acharya A N, Mohanty P and Das A 1998 Int. J. Chem. Kinet. 30373

30. Fukuhara C, Tsuneyoshi K, Mitsumoto N, Kida S, Mikuriya M and Mori M 1990 J. Chem. Soc., Dalton Trans. 3473

31. Maragh P T, Dasgupta T P and Williams D J $1995 \mathrm{~J}$. Chem. Soc., Dalton Trans. 2843

32. Capparelli M V and Becka L N 1969 J. Chem. Soc. (A) 260

33. Elder R C, Heeg M J, Payne M, Dm Trukla M and Deutsch 1978 Inorg. Chem. 17431 